\title{
Combination of nitric oxide and 1-MCP on postharvest life of the blueberry (Vaccinium spp.) fruit
}

\author{
Gustavo Esteban Gergoff Grozeff ${ }^{a, b, c, *}$, Matías Leonel Alegre ${ }^{a}$, María Eugenia Senn ${ }^{\text {, }}$ \\ Alicia Raquel Chaves ${ }^{\mathrm{d}}$, Marcela Simontacchi ${ }^{\mathrm{a}}$, Carlos Guillermo Bartoli ${ }^{\mathrm{a}}$ \\ a Instituto de Fisiología Vegetal CCT CONICET La Plata, Universidad Nacional de La Plata, Facultad de Ciencias Agrarias y Forestales, Facultad de Ciencias Naturales y \\ Museo, Diagonal 113 № 495, 1900 La Plata, Argentina \\ b Laboratorio de Investigación en Productos Agroindustriales (LIPA), Facultad de Ciencias Agrarias y Forestales-UNLP, Calle 60 y 119 s/n, 1900 La Plata, Argentina \\ c Cursos de Fruticultura y Fisiología Vegetal, Facultad de Ciencias Agrarias y Forestales - UNLP, Calle 60 y $119 \mathrm{~s} / \mathrm{n}$, 1900 La Plata, Argentina \\ d Centro de Investigación y Desarrollo de Criotecnología de Alimentos CCT CONICET La Plata, Facultad de Ciencias Exactas (UNLP), 47 y 116, 1900 La Plata, Argentina
}

\section{A R T I C L E I N F O}

\section{Keywords:}

Ascorbic acid

Berries

Citric acid

Dehydroascorbic acid

Glutathione

Malic acid

\begin{abstract}
A B S T R A C T
Blueberries are a perishable fruit that loses its firmness and weight rapidly after harvest. High concentrations of ascorbic acid (AA) and phenolic compounds such as anthocyanins are important attributes contributing to the quality of the fruit. The aim of this work is to extend the postharvest life of three blueberries cultivars; 'Mistý and 'Blue Cuinex́, firm and soft cultivars respectively and 'Blue Chiṕ with intermediate firmness. The fruit was treated separately or in combination with a nitric oxide donor, S-nitrosoglutathione (GSNO) and 1-methylcyclopropene (1-MCP) and stored at $4{ }^{\circ} \mathrm{C}$ for $14 \mathrm{~d}$. The best treatment for 'Blue Cuinex was the combination of 1MCP and GSNO, while 'Mistý softened slower when treated with 1-MCP, and 'Blue Chiṕ was not affected by treatment. The 1-MCP + GSNO treatment maintained higher concentrations of AA and GSH in 'Blue Cuinex́. AA concentrations declined in 'Mistý but did not respond to GSNO. The combination of 1-MCP and GSNO extended the postharvest life of 'Blue Cuinex́ by improving the concentrations of AA and glutathione in the berries but not for 'Mistý. These results demonstrate that blueberry cultivars respond differentially to 1-MCP and nitric oxide, and that the sequence of application could be used to slow fruit softening and maintain antioxidant properties.
\end{abstract}

\section{Introduction}

Blueberries are a type of fruit commonly named "berries" or "fruit of the forest". Fruit of this heterogeneous group of species has high levels of antioxidants but are extremely perishable (Kader, 2002; PerkinsVeazi, 2016).

Blueberries are classified as climacteric fruit that show a moderate respiration rate and a low ethylene production compared with other fruit and with an average potential storage life of two weeks (Kader, 2002). To minimize damage and to improve postharvest life, blueberry fruit should be handled carefully and packed directly into small containers (Miller and McDonald, 1988).

Many studies related to blueberry's postharvest life extension have focused on the effects of treatments like cold temperature (Connor et al., 2002), high oxygen atmospheres (Zheng et al., 2003), edible coatings (Duan et al., 2011), ultraviolet radiation (Perkins-Veazi et al., 2008), 1-methylcyclopropene (1-MCP) (DeLong et al., 2003; Chiabrando and Giacalone, 2011) and many others.

The production of ethylene in blueberries depend on the ripening stage: when fruit turns a pink color, there is a peak of ethylene production and when the fruit develops to full color, the production of this hormone returns to the basal level (El-Agamy et al., 1982). The application of an inhibitor of the action of ethylene (aminoethoxyvinylglycine) retards the ripening process of the blueberry fruit (Dekazos, 1979), while ethephon accelerates ripening, stimulating fruit softening and decreasing the titratable acidity (Ban et al., 2007).

Little contribution of the ethylene receptor inhibitor, 1-MCP, has been found in blueberries (DeLong et al., 2003; Chiabrando and Giacalone, 2011) and MacLean and NeSmith (2011) found that 1-MCP stimulated ethylene production in three different cultivars and accelerated the rate of firmness loss. Ethylene synthesis in blueberries is still not completely understood.

Nitric oxide (NO) is a bioactive molecule synthesized by plants that has important physiological functions. It is also involved in responses to stress conditions (Kopyra and Gwóźdź, 2003; Hung et al., 2002; Simontacchi et al., 2015). NO is a highly reactive molecule and it is assumed to react with a variety of targets including protein modifications (S-nitrosylation), tyrosine nitration and metal nitrosylation.

\footnotetext{
* Corresponding author.

E-mail address: gergoff.gustavo@agro.unlp.edu.ar (G.E. Gergoff Grozeff).
} 
Ethylene and NO have antagonistic effects in climacteric fruit (Liu et al., 2007), since NO decreases ethylene synthesis, during ripening and fruit senescence. Possibly this interaction could be at the hormone receptors level: ethylene requires a transitions metal cofactor, copper, to bind to the receptors (Rodriguez et al., 1999) and it is possible that NO could affect this binding process. NO increases the activity of antioxidant enzymes (Flores et al., 2008; Kopyra and Gwóźdź, 2003), and also has been suggested as an antisenescent molecule (Jasid et al., 2009). NO has been used to extend postharvest life in strawberries (Wills and Leshem, 2000), delaying ripening and alleviating chilling injury in mangos (Zaharah and Zora, 2011) and Japanese plums (Singh et al., 2009). A complete list of these studies is mentioned in Manjunatha et al. (2010). The application of sodium nitroprusiate (a NO donor) to a nonclimacteric fruit, such as strawberry, decreases the synthesis of ethylene, reducing the content of ACC (1-Aminocyclopropane-1-carboxylic acid) synthase (Zhu and Zhou, 2007); meanwhile in peach, a climacteric fruit, the effect was similar, but the target was the inhibition of the ACC oxidase (Zhu et al., 2006). Additionally, NO has been involved in reducing softening in bananas, affecting the enzymes for the synthesis pathway of ethylene and cell-wall disabling, such as polygalacturonase and pectin methylesterase (Cheng et al., 2009).

The characterization of quality parameters in different cultivars is an important starting point for studying the postharvest biology of blueberries. Within the quality parameters, fruit firmness is an important economic trait for fresh blueberries for the market (Ehlenfeldt and Martin, 2002). The cultivars of blueberries studied in this work were chosen from the previous work of Ehlenfeldt and Martin (2002). 'Blue Chiṕ has intermediate firmness, while 'Mistý is presented as one the firmest fruits. 'Blue Cuinex́ was chosen due to its importance in the concert of cultivars produced in Argentina and for its quick loss of firmness during postharvest.

The objective of this work was to improve the postharvest life of three different cultivars of blueberries by the application of an ethylene response suppressor (1-MCP) in combination with a NO donor [S-nitrosoglutathione (GSNO)].

\section{Materials and methods}

\subsection{Plant material, experimental setup and treatments}

\subsubsection{Experiment I}

Blueberry fruit (Vaccinium corymbosum cvs. 'Blue Cuinex́ and 'Blue Chiṕ and $V$. corymbosum $x$ darrowii cv. 'Mistý) was harvested from the orchard of the Experimental Station Julio A. Hirschhorn (National University of La Plata), located in Los Hornos, La Plata, Argentina (34 $59^{\prime} \mathrm{S}, 57^{\circ} 59^{\prime} \mathrm{W}$ ). The experiments were started in the last week of November 2012. The fruit was harvested when color reached $100 \%$ of the surface, placed in perforated clamshells containing $125 \mathrm{~g}$ each (approximately 30 fruit) and immediately transported to the laboratory. Twelve clamshells per treatment were prepared for each treatment and cultivar (48 clamshells in total for each cultivar). Clamshells containing fruit of the three cultivars were first divided into two groups and placed in a $40 \mathrm{~L}$ air tight chamber for treatment with $0 \mu \mathrm{LL}^{-1}$ or $1 \mu \mathrm{L} \mathrm{L}^{-1}$ of 1 -MCP (Smart Fresh ${ }^{\mathrm{SM}}$ ) for $12 \mathrm{~h}$ at $23^{\circ} \mathrm{C}$. The two groups of clamshells were then divided and treated with a $10 \mathrm{~mL}$ of water or $10 \mathrm{~mL}$ of $1 \mathrm{mmol} \mathrm{L}^{-1}$ GSNO solution. In a $25 \mathrm{~L}$ closed chamber connected to a nebulizer to produce extremely small drops of solution that ensured the even distribution of the liquid for $30 \mathrm{~min}$. The fruit was then carefully placed again in their respectively clamshells and stored at $4{ }^{\circ} \mathrm{C}$ for $14 \mathrm{~d}$. Samples were taken at 0,7 and $14 \mathrm{~d}$ after treatment. For each sample, at least ten fruit were taken from the clamshells. Measurements of weight loss, color and firmness were taken with at least six fruits from each of the six clamshells. The rest of the fruit was frozen in liquid nitrogen and stored at $-80{ }^{\circ} \mathrm{C}$ until used for the rest of the measurements. Each sample consisted of ten fruit from each of the six clamshells.

\subsubsection{Experiment II}

'Mistý and 'Blue Cuinex́ fruit were harvested from the same orchard at the Experimental Station Julio A. Hirschhorn (National University of La Plata). Three independent experiments were performed starting in the last week of November 2012, 2014 and 2015, each consisting of three biological replicates. Fruit was harvested when color reached $100 \%$ of the surface, placed in perforated clamshells containing $125 \mathrm{~g}$ each (approximately 30 fruit) and immediately transported to the laboratory. Eighteen clamshells per treatment and harvest year were prepared for each cultivar. Treatments were performed as described in Experiment I, except that samples were taken at 0, 2, 7 and $14 \mathrm{~d}$ after harvest. Respiration rates were measured using three clamshells per treatment and sampling day ( 9 measurements in the three years). Once the measurements were finished, ten fruit were removed from each clamshell, frozen in liquid nitrogen and stored at $-80^{\circ} \mathrm{C}$ until use for the rest of the measurements. For each biochemical measurements, six samples of ten fruit each were taken from separate clamshells for each treatment, time of sampling and year of harvest.

\subsubsection{Climatic data}

Climatic data was recorded with a weather station (Davis Instruments Corporation model GroWeather Industrial, California, USA) located at $34^{\circ} 59^{\prime} \mathrm{S}, 57^{\circ} 59^{\prime} \mathrm{W}, 45 \mathrm{~m}$ above sea-level. The data was analyzed and kindly provided by Agronomist H. Martín Pardi from the Agrometeorology Section of the Experimental Station Julio A. Hirschhorn and Course of Agricultural Climatology and Phenology (Faculty of Agricultural and Forestry Sciences, National University of La Plata). Data was recorded daily during all the growing seasons of 2012, 2013, 2014 and 2015. Global radiation and mean, maximum and minimum temperatures were calculated as an average of these recordings for every month.

\subsection{Weight loss}

Weight loss was measured in 6 replicates, each consisting of $125 \mathrm{~g}$ fruit per clamshell per season per treatment. Fruit was weighed at 0,7 and $14 \mathrm{~d}$ after harvest and fruit weight loss (WL) was calculated as follows: $\mathrm{WL}=\left[\left(\mathrm{W}_{\mathrm{i}}-\mathrm{W}_{\mathrm{f}}\right)\left(\mathrm{W}_{\mathrm{i}}\right)^{-1}\right] \times 100 . \mathrm{W}_{\mathrm{i}}$ is the initial weight and $\mathrm{W}_{\mathrm{f}}$ is the final weight of each sample of fruit. The results are expressed as percentage for each period of sampling.

\subsection{Color and anthocyanins determinations}

Fruit skin color was measured with a colorimeter (Minolta ${ }^{\circledR}, \mathrm{CR}-400$, Osaka, Japan) to obtain $\mathrm{L}^{*}, \mathrm{a}^{*}$ and $\mathrm{b}^{*}$ values. Thirty replicates taken from different clamshells were performed for each cultivar, harvest season and treatment at 0 and $14 \mathrm{~d}$ after harvest. Anthocyanins were extracted according to Angeletti et al. (2010) and measured at $515 \mathrm{~nm}$ with a UV-vis recording spectrophotometer (Shimadzu UV-160A, Japan). Each measurement was made at harvest and after 2, 7 and $14 \mathrm{~d}$ of cold storage at $4{ }^{\circ} \mathrm{C}$. The results were calculated as $\mu \mathrm{mol}$ of cyanidin3-glucoside by using $\varepsilon=29.000 \mathrm{M}^{-1} \mathrm{~cm}^{-1}$. Results are expressed in $\mathrm{g}$ of total anthocyanins per $\mathrm{kg}$ on a fresh weight basis.

\subsection{Total soluble solids, titratable acidity and $\mathrm{pH}$}

For total soluble solids (TSS), $10 \mathrm{~g}$ of fruit was macerated using a mortar and pestle, and a few drops of the juice were placed in a refractometer (Milwaukee MA871, Rocky Mount, USA). Results are expressed in percentage (\%). $\mathrm{pH}$ was potentiometrically measured $(\mathrm{pH}$ meter Hanna Edge ${ }^{\circ}$ ) and total titratable acidity (TTA) was determined titrimetrically with a $0.1 \mathrm{~mol} \mathrm{~L}^{-1}$ solution of $\mathrm{NaOH}$ until $\mathrm{pH} 8.2$ was reached (AOAC, 1980). Results are expressed as $\mathrm{g}$ of citric acid per $\mathrm{kg}$ of fruit fresh weight basis. 


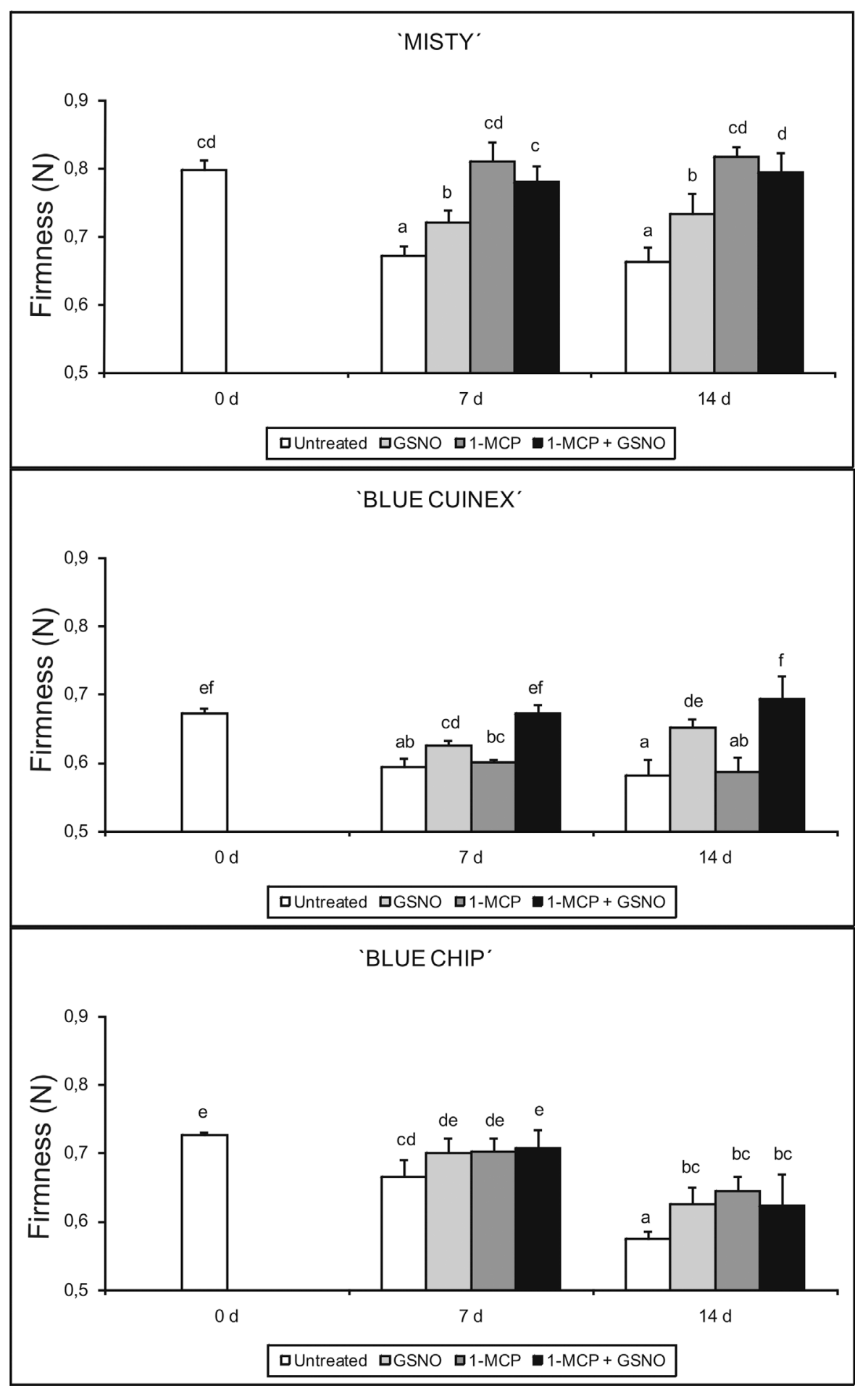

Fig. 1. Firmness in untreated, GSNO, 1-MCP and 1-MCP + GSNO treated blueberries fruits of cvs. 'Mistý, 'Blue Cuinex́ and 'Blue Chiṕ at harvest (0d) and after storage for 7 and $14 \mathrm{~d}$ at $4{ }^{\circ} \mathrm{C}$. Columns represent the mean of three independent experiments with three replicates each and bars represent the standard deviation. Values with different letters are different at $\mathrm{P}<0.05$.

\subsection{Determination of ascorbic acid and glutathione}

Blueberries were taken from the $-80^{\circ} \mathrm{C}$ freezer and were macerated using mortar and pestle with a $3 \% \mathrm{v} / \mathrm{v}$ trifluoracetic acid solution in ice. Samples were centrifuged at $16,000 \times g$ for $10 \mathrm{~min}$. Supernatant was separeted for AA and dehydroascorbate (DHA) measurements. The concentration of AA and its oxidized form, DHA, was measured by HPLC according to Bartoli et al. (2006) with minimal modifications. The redox state of AA was calculated as: $\%$ DHA $=$ [(DHA content) $\left.(\text { AA content }+ \text { DHA content })^{-1}\right] \times 100$.

The concentration of total (GSH + GSSG) and oxidized glutathione (GSSG) was measured according to Griffith (1980). The redox state of
GSH was calculated as: \% GSSG $=$ [(GSSG content) (GSH content + GSSG content $)^{-1}$ ] $\times 100$.

AA and GSH concentrations are expressed in the basis of fresh weight.

\subsection{Determination of citric and malic acid}

Citric and malic acids were extracted from frozen fruit tissues macerated with a $6 \%(\mathrm{v} / \mathrm{v})$ orto-phosphoric acid solution in a mortar and pestle and centrifuged at $16,000 \times g$ for $10 \mathrm{~min}$. Supernatant was separated for citric and malic acid measurements by HPLC according to Romero Rodriguez et al. (1992) with minimal modifications. Results are 
expressed as mmol of citric or malic acid per $\mathrm{kg}$ of fresh weight.

\subsection{Respiration rate}

The production of $\mathrm{CO}_{2}$ by fruit respiration was measured with an infrared sensor (Lutron Electronic Enterprise Co. L.T.D., Model GC2028). $60 \mathrm{~g}$ of fruit for each replicate was allowed to warm $\left(24^{\circ} \mathrm{C}\right)$ and then placed in a $5.6 \mathrm{~L}$ hermetic flask for $20 \mathrm{~min}$. The amount of $\mathrm{CO}_{2}$ produced by respiration was recorded every minute during the incubation. Results were plotted and the respiration rate was estimated by a regression line. Three samples were measured for each variety, treatment and harvest season. Results are expressed in $\mathrm{mmol}$ of $\mathrm{CO}_{2}$ produced per $\mathrm{kg}$ per $\mathrm{h}$ on a fresh weight basis.

\subsection{Firmness}

Fruit firmness was measured with a texture analyzer (T.A.) (Exponent Texture Analyzer TA.XT.PLUS from Stable Micro Systems ${ }^{\mathrm{TM}}$ Goldalming, Surrey, UK). T.A. was equipped with a $10 \mathrm{~mm}$ diameter flat probe. Fruit were deformed for a distance of $0.5 \mathrm{~mm}$ at a speed of $0.25 \mathrm{~mm} \mathrm{~s}^{-1}$ and a $0.058 \mathrm{~N}$ trigger force was used. Sixty fruit were analyzed for each cultivar, treatment, postharvest time and harvest season. Results are expressed in Newtons.

\subsection{Statistical analysis}

The data is presented as the average of the results obtained from two independent experiments (season 2012 for experiment I and seasons 2012, 2014 and 2015 for experiment II) with a minimum of 6 replicates each year. The experimental layout was a completely randomized design.

The data was analyzed by means of one way ANOVA. The means were compared with the Last Significant Difference (LSD) test at a significance level of 0.05 . Statistical analysis was performed with Statistica 6.0 software from StatSoft.

\section{Results}

\subsection{Experiment $I$}

\subsubsection{Fruit firmness and weight loss}

'Mistý fruit had the highest firmness $(0.80 \mathrm{~N})$ compared to 'Blue Cuinex́ $(0.67 \mathrm{~N})$ and 'Blue Chiṕ $(0.73 \mathrm{~N})$.

Untreated fruit of 'Mistý showed a rapid decrease in firmness at $7 \mathrm{~d}$ of storage, maintaining this value till the end of the experiment (Fig. 1), 1-MCP alone or in combination with GSNO exhibited the highest firmness values with no statistical differences between them, while the GSNO treated fruit showed intermediate values in all the cases (Fig. 1).

'Blue Cuinex́ demonstrated similar patterns at $7 \mathrm{~d}$ after cold storage to those of 'Mistý, but differences were evident $14 \mathrm{~d}$ after storage at $4{ }^{\circ} \mathrm{C}$ with the combination of 1-MCP and GSNO (Fig. 1).

'Blue Chiṕ fruit showed a constant loss of firmness during storage with no effects of treatments (Fig. 1).

During storage, 'Mistý lost close to $1 \%$ of weight by $14 \mathrm{~d}$ of cold storage, and the combination of 1-MCP with GSNO resulted in the best treatment for this cultivar at $14 \mathrm{~d}$ after harvest (Fig. 2). Similar effects were found for 'Blue Cuinex́ while no effects were found for 'Blue Chiṕ after treatment (Fig. 2).

\subsubsection{Fruit quality attributes}

Neither the $\mathrm{pH}$, nor the total titratable acidity was modified significantly compared with untreated fruit (Supplementary Tables 1A, 1 B and 1C). TSS showed a slight decrease at $7 \mathrm{~d}$ in 'Mistý treated fruit with the GSNO, 1-MCP and 1-MCP + GSNO compared with the untreated fruit. After $14 \mathrm{~d}$ of cold storage, 1-MCP + GSNO TSS of 'Mistý fruit decreased further compared with the untreated one (Supplementary

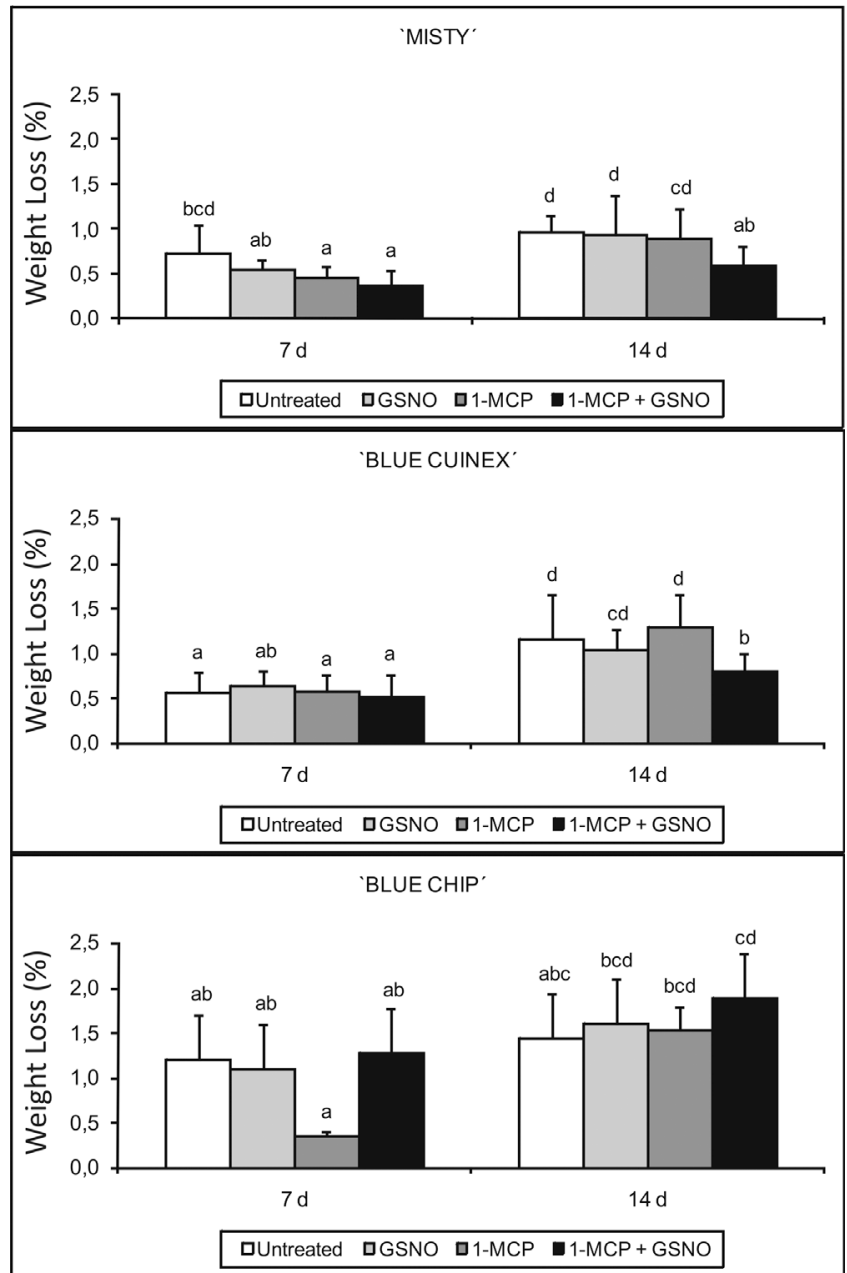

Fig. 2. Weight loss in untreated, GSNO, 1-MCP and 1-MCP + GSNO treated blueberries fruits of cvs. 'Mistý, 'Blue Cuinex́ and 'Blue Chiṕ at harvest (0d) and after storage for 7 and $14 \mathrm{~d}$ at $4{ }^{\circ} \mathrm{C}$. Columns represent the mean of three independent experiments with three replicates each and bars represent the standard deviation. Values with different letters are different at $\mathrm{P}<0.05$.

Tables 1A). TSS of 'Blue Cuinex́ fruit remained the same regardless of treatment or the harvest time (Supplementary Table 1B) and total titratable acidity of 1-MCP and GSNO 'Blue Chiṕ increased slightly at 14 $\mathrm{d}$ after harvest (Supplementary Table 1C). The $\mathrm{a}^{*}$ or $\mathrm{b} *$ values of the three cultivars were not affected by treatment. 'Mistý fruit treated with GSNO, 1-MCP and 1-MCP + GSNO showed a slight increase in the L* value after $14 \mathrm{~d}$ of cold storage, but not in 'Blue Cuinex́ or 'Blue Chiṕ fruit (Supplementary Table 2).

\subsection{Experiment II}

\subsubsection{Climatic data}

Temperatures and total radiation measured in the field were not significantly different during the three seasons when the experiments were performed (Supplementary Fig. 1). Remberg et al. (2006) found that climate and growing season had minor effects on blueberry fruit quality.

\subsubsection{Respiration rate}

'Mistý fruit has $50 \%$ higher respiration rate than 'Blue Cuinex́ fruit at $0 \mathrm{~d}$, but no differences were observed during storage. Two days after cold storage, 'Mistý fruit treated with the combination of 1-MCP + GSNO had higher respiration rates. Seven days after cold storage, 1MCP + GSNO fruit maintained the highest respiration rate, similarly to that of GSNO alone. The respiration rate of the untreated fruit at this 

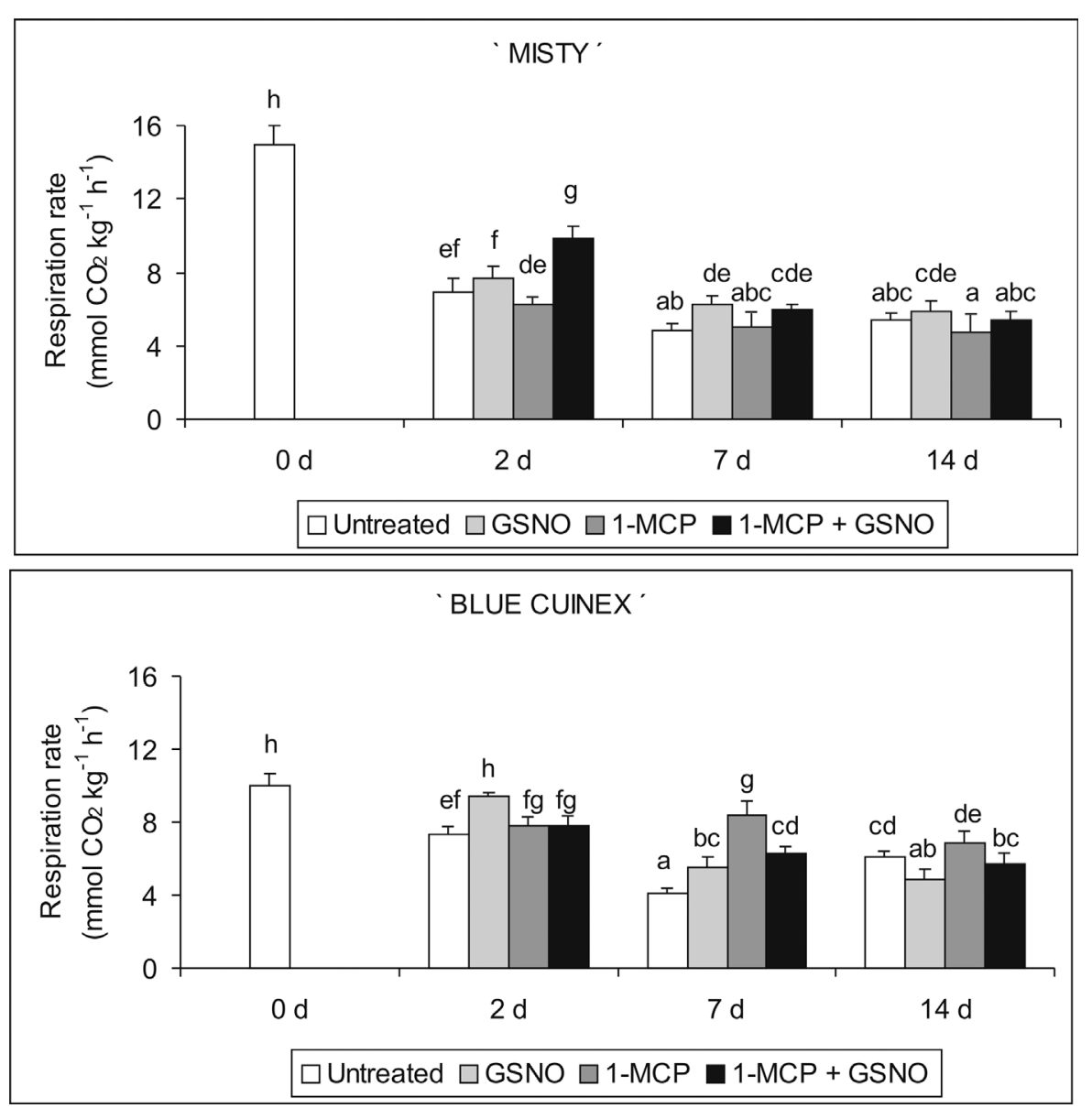

Fig. 3. Respiration rate in untreated, GSNO, 1-MCP and 1MCP + GSNO treated blueberries fruits of cvs. 'Mistý and 'Blue Cuinex́ at harvest (0d) and after storage for 2, 7 and 14 $\mathrm{d}$ at $4{ }^{\circ} \mathrm{C}$. Columns represent the mean of three independent experiments with three replicates each and bars represent the standard deviation. Values with different letters are different at $\mathrm{P}<0.05$. time decreased in average to $4.83 \mathrm{mmol}$ of $\mathrm{CO}_{2} \mathrm{~kg}^{-1} \mathrm{~h}^{-1}$. Fourteen days after cold storage at $4{ }^{\circ} \mathrm{C}$, all the treatments showed the lowest respiration rates with an average value of $5.36 \mathrm{mmol}$ of $\mathrm{CO}_{2} \mathrm{~kg}^{-1} \mathrm{~h}^{-1}$ (Fig. 3).

The respiration rate of 'Blue Cuinex́ was lower at harvest, the decrease was not so marked at $2 \mathrm{~d}$ after cold storage as with 'Mistý. At this time, GSNO treated fruit maintained a similar respiration rate to that at harvest, while the respiration rate of fruit in the other treatments decreased, and the rest of the treatments decreased the respiration rate. At $7 \mathrm{~d}$ of cold storage the decrease in this rate was more evident in all treatments, except for the 1-MCP treated fruit. The reduction in the respiration rate continued $14 \mathrm{~d}$ after cold storage (Fig. 3).

\subsubsection{Malic acid, citric acid and anthocyanin concentrations}

Malic acid concentration in 'Mistý fruit increased slightly in all treatments after $2 \mathrm{~d}$ compared with that at harvest time. The concentration increased by 4 times in the GSNO treated fruit at $7 \mathrm{~d}$ after harvest, returning to the level at harvest by $14 \mathrm{~d}$ (Fig. 4A).

A similar effect was observed in 'Blue Cuinex́ fruit after $2 \mathrm{~d}$ at $4{ }^{\circ} \mathrm{C}$. The fruit treated with 1-MCP, GSNO and 1-MCP + GSNO maintained the malic acid concentration more than the untreated fruit at the same time. An increase in the production of malic acid was reached in untreated and GSNO treated fruits at $7 \mathrm{~d}$ and this difference was maintained until the end of the experiment (Fig. 4B).

'Mistý had similar citric acid concentration in all fruit on d 2. On d 7 a 4 fold increase in citric acid concentration was found in the GSNO treated fruit, while at $14 \mathrm{~d}$ it decreased in the 1-MCP + GSNO treated fruit compared with the rest of the treatments (Fig. 4C). In contrast, citric acid in 'Blue Cuinex́ declined with no differences among treatments at $2 \mathrm{~d}$. At $14 \mathrm{~d}$ after cold storage there was a tendency for the untreated and 1-MCP treated fruits to reach similar values at the harvest time. The GSNO treated fruit showed an intermediate value and the 1-MCP + GSNO treatment provoked a reduction in the citric acid concentration at $14 \mathrm{~d}$ in 'Blue Cuinex́ fruit (Fig. 4D).

Anthocyanin concentrations were not affected by treatment in either 'Mistý or 'Blue Cuinex́ fruit (Supplementary Fig. 2).

\subsubsection{Concentration and redox state of ascorbic acid and glutathione}

Untreated and 1-MCP treated 'Mistý fruit maintained the same concentration of AA at d 2 as seen at harvest time, but concentrations declined slightly in the GSNO and in the 1-MCP + GSNO treated fruit (Fig. 5A). Fruit maintained the amount of AA concentration compared from the harvest day to $7 \mathrm{~d}$ of cold storage in the 1-MCP treated fruit, the 1-MCP + GSNO treated fruit and decrease slowly at $14 \mathrm{~d}$ showing 1-MCP and 1-MCP + GSNO treatments had a significant difference with the untreated and the GSNO treatment (Fig. 5A). The redox state of the AA was not modified, except in the GSNO treated fruit on d 14 (Fig. 5B).

'Blue Cuinex́ blueberries at $2 \mathrm{~d}$ after cold storage manifested a decrease in the AA content, but not in the 1-MCP + GSNO treated fruit that maintained the same level of this antioxidant. After $7 \mathrm{~d}$ GSNO and 1-MCP + GSNO treatments increased the AA content and the raise was more pronounced at d14. Interestingly, the GSNO and the 1-MCP + GSNO treatments showed a $63 \%$ and a $114 \%$ increase in this vital antioxidant at $14 \mathrm{~d}$ after harvest. At 2 and $7 \mathrm{~d}$ after harvest, 'Blue Cuinex́ blueberries showed variable values of the redox state of AA (Fig. 5D). At $14 \mathrm{~d}$ after cold storage, there were no significant differences between untreated and treated fruit, with the exception of the 1MCP + GSNO which presented a slight decrease in the DHA $\%$ (Fig. 5D).

'Mistý fruit showed an increase of the content of glutathione at $2 \mathrm{~d}$ of cold storage in GSNO and 1-MCP treatments, but this effect was more notorious in the GSH content of the GSNO treated fruit (Fig. 6A). After 7 


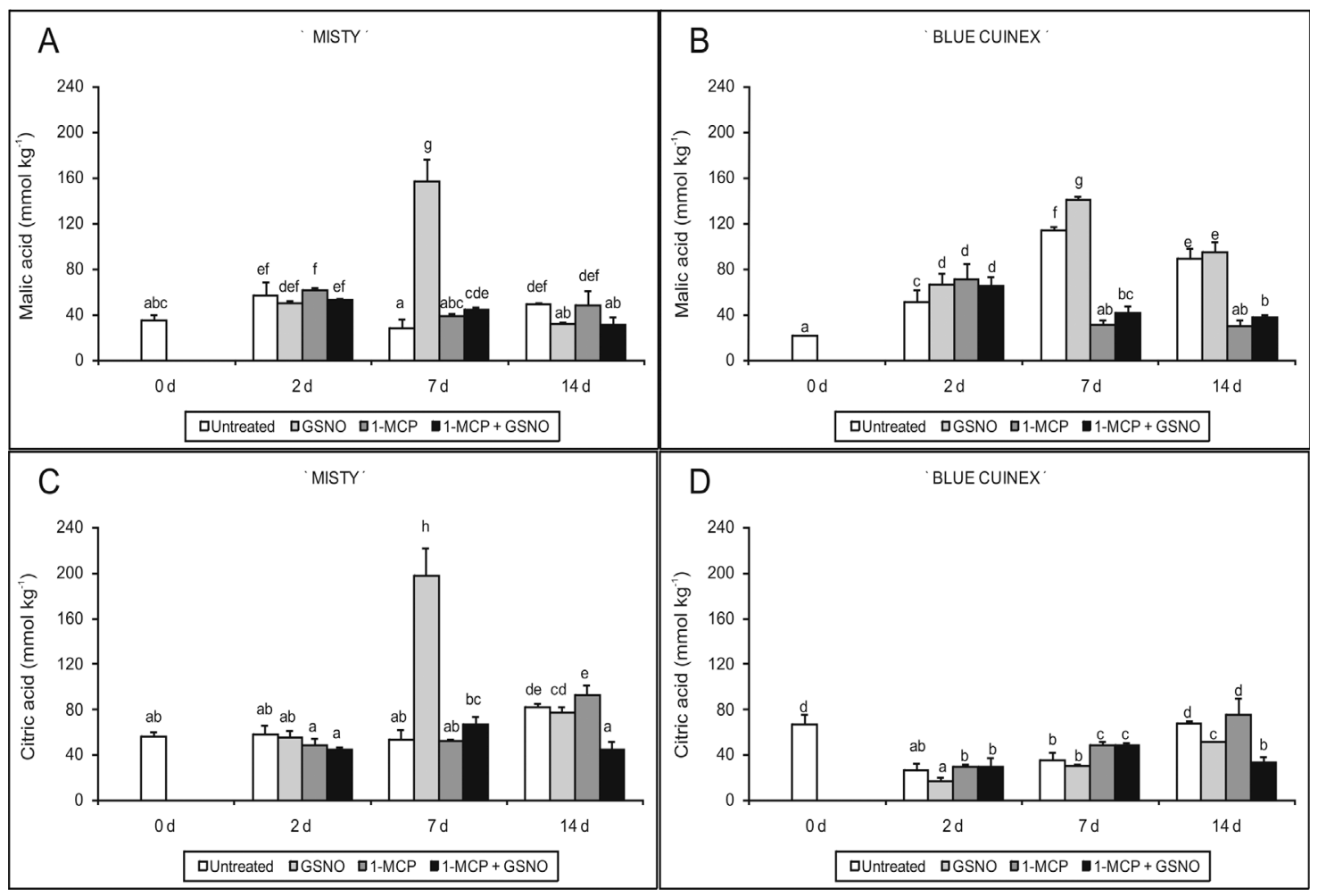

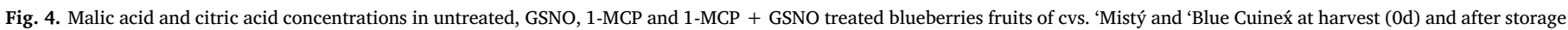

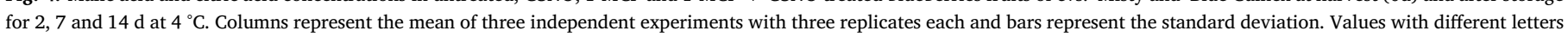
are different at $\mathrm{P}<0.05$.

d the decrease in GSH content was significant in all treatments, with some recovering at $14 \mathrm{~d}$, especially in the untreated and 1-MCP treated fruit. The amount of GSH was maintained in more reduced values in the 1-MCP + GSNO treated fruit at 7 and $14 \mathrm{~d}$ after storage (Fig. 6A).

Concomitant with the effects founded in the content of AA, GSH concentration (Fig. 6C) partially mimics the pattern of AA in 'Blue Cuinex́ fruit (Fig. 5C). At $2 \mathrm{~d}$ GSNO and 1-MCP treatments showed a significant increase in the GSH concentration. At $7 \mathrm{~d}$ 'Blue Cuinex́ fruit did not show any differences while at $14 \mathrm{~d}$ the untreated fruit showed a strong decrease and fruit with GSNO or 1-MCP treatments showed values similar to that of harvest time $(0 \mathrm{~d})$. At this point the concentration of glutathione increased three times compared to $0 \mathrm{~d}$ (Fig. 6C) coinciding with a decrease in the redox state (Fig. 6D). In other words, the more reduced glutathione and less oxidized glutathione improves the content of AA and its turnover to the reduced form.

\section{Discussion}

Firmness of blueberry fruit is critical (Ehlenfeldt and Martin, 2002; Vicente et al., 2007) and the strategy of the first experiment was to select different cultivars of blueberries that have different softening patterns during cold storage using 1-MCP, GSNO or the combination of
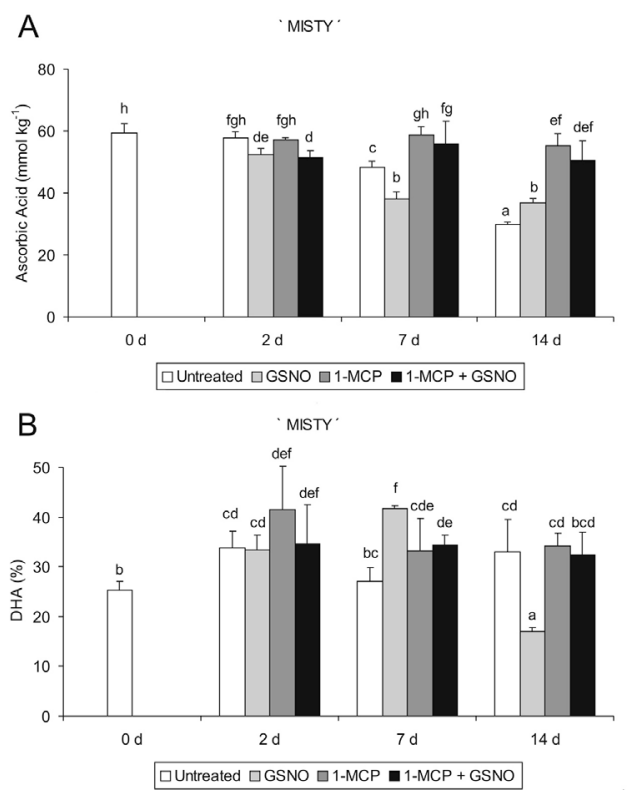

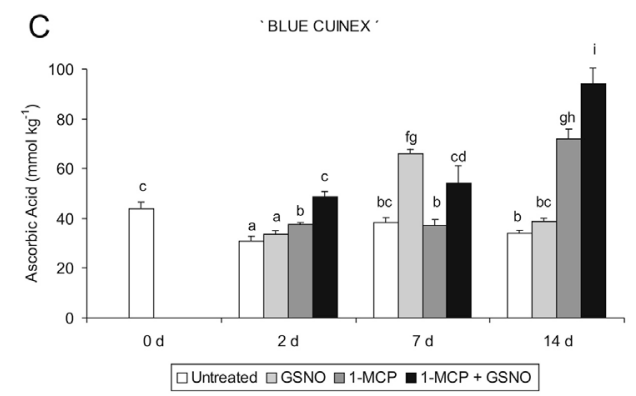

$\mathrm{D}$

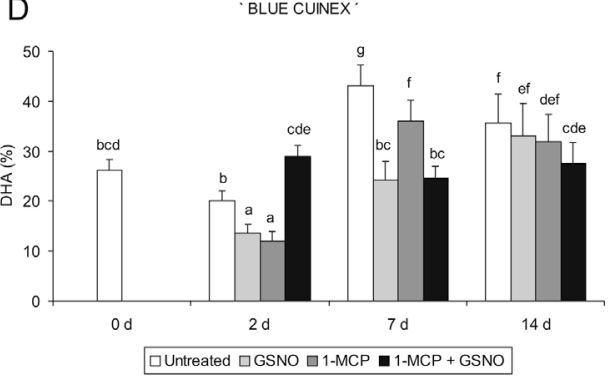

Fig. 5. Ascorbic acid concentrations and its redox state (DHA\%) in untreated, GSNO, 1-MCP and 1MCP + GSNO treated blueberries fruits of cvs. 'Mistý and 'Blue Cuinex́ at harvest (0d) and after storage for 2,7 and $14 \mathrm{~d}$ at $4{ }^{\circ} \mathrm{C}$. Columns represent the mean of three independent experiments with three replicates each and bars represent the standard deviation. Values with different letters are different at $\mathrm{P}<0.05$. 
A

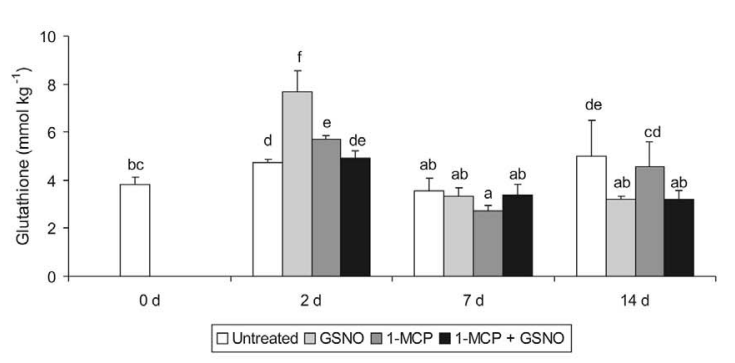

B

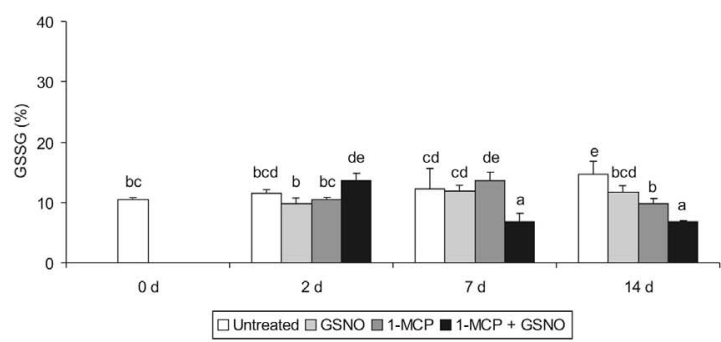

C

BLUE CUINEX

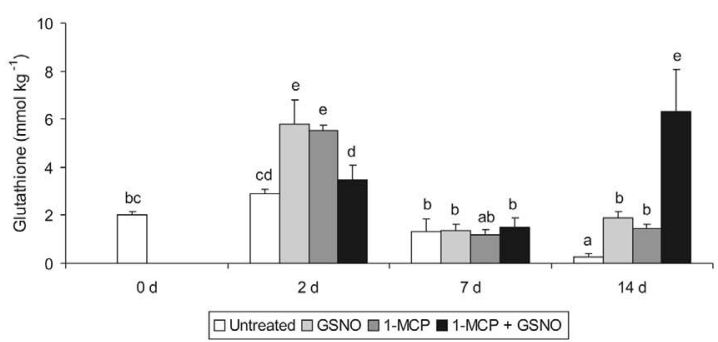

D BLUE CUINEX'

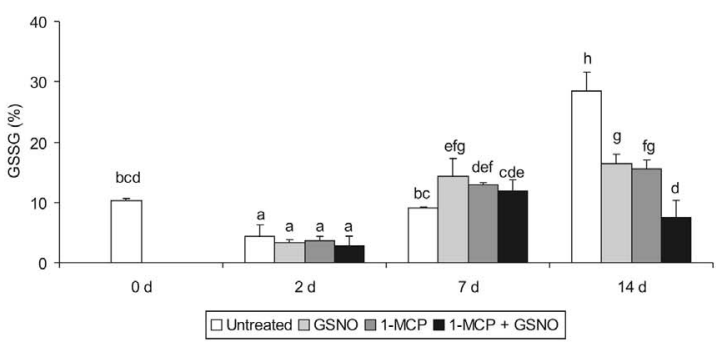

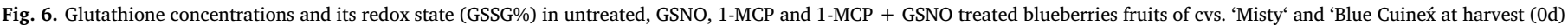

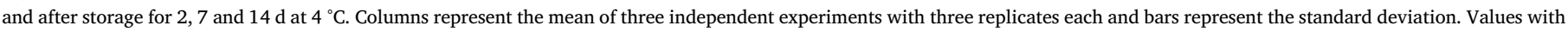
different letters are different at $\mathrm{P}<0.05$.

both. Based on these results, 'Mistý and 'Blue Cuinex́ were chosen because of their different softening patterns. A more detailed biochemical characterization was performed to understand the AA and GSH progress during postharvest after 2,7 and $14 \mathrm{~d}$ of cold storage at $4{ }^{\circ} \mathrm{C}$.

\subsection{The combination of 1-MCP and GSNO improved firmness and decreased weight loss}

Softening is a consequence of the modification in the content of different cell wall polymers and these modifications in blueberry fruit have been studied by Angeletti et al. (2010) and Vicente et al. (2007). In the case of blueberries, fruit softening is a result of hemicellulosic depolymerization (Vicente et al., 2007), while elasticity is a consequence of fruit turgor (Fava et al., 2006). In this work, the firmness was maintained with the 1-MCP treatment in 'Mistý and with the combination of 1-MCP and GSNO treatment in 'Blue Cuinex́. Firmness of 'Blue Chip was improved with the 1-MCP or GSNO treatment alone, or in combination (Fig. 1).

Paniagua et al. (2013) demonstrated that there is a close relationship between weight loss and firmness in blueberries. The firmness and weight loss occur together (Figs. 1 and 2). This suggests that weight loss could modify cell turgidity, leading to an effect on firmness in the combination treatment of 1-MCP and GSNO in both cultivars. This effect is especially evident in 'Blue Cuinex́, the one with the lowest firmness at harvest (Fig. 1).

In both cases, 'Mistý and 'Blue Cuinex́ have moderate water loss compared with other cultivars that reach nearly $6 \%$ of water loss at 14 $\mathrm{d}$ after harvest (Angeletti et al., 2010). The maximum weight loss was reached by the untreated fruit of 'Blue Chip $14 \mathrm{~d}$ after harvest was above $1.9 \%$ (Fig. 1) above the $8 \%$ limit of acceptance by the consumers (Paniagua et al., 2013).

\subsection{Respiration and concentrations of citric and malic acids}

Respiration rate decreased after harvest but this was more pronounced in 'Mistý blueberries $2 \mathrm{~d}$ after harvest (Fig. 3). Although the results in this parameter displayed some differences between treatments, there is a tendency towards lower respiration rates in fruit stored for $14 \mathrm{~d}$ at $4{ }^{\circ} \mathrm{C}$ (Fig. 3).

Organic acids in fruit can vary between closely related species of
Vaccinium spp. or even among cultivars giving a particular pattern of acids and consequently a different flavor profile (Ehlenfeldt et al., 1994). In Vaccinium spp. the most abundant organic acids are citric, succinic, malic and quinic, depending on the cultivar (Ehlenfeldt et al., 1994) or on the maturation stage (Ayaz et al., 2001). During the fruit growth period malic acid shows an increase from unripe to ripe fruit while quinic and citric acid descends in their content in some Vaccinium species (Ayaz et al., 2001). The effect of the decrease in the total titratable acidity and the increase in the total sugars content were found in other V. corymbosum cultivars by Rodarte Castrejón et al. (2008).

Different Krebs cycle acids act in many metabolic pathways and they are oxidized by mitochondria during respiration in plants (Araujo et al., 2011). In our case, there was not a clear relation between respiration rates and organic acid concentration after harvest. There was a coincidence in the raise of malic and citric acid in GSNO treated fruit of 'Mistý at $7 \mathrm{~d}$ after harvest with no correlation with the respiration rate. Further work dealing with this organic acid metabolism should be developed in future postharvest research.

\subsection{AA and GSH can be improved with the combination of 1-MCP and GSNO}

Considering the total antioxidant capacity of blueberries, AA plays a central role over other antioxidants (Atala et al., 2009). It has been shown that some cultivars of blueberries show an increase of their total antioxidant capacity when they are in cold storage and at the end this antioxidant activity returns to that at harvest time (Connor et al., 2002). AA concentrations can vary widely among different cultivars (Gündüz et al., 2015), and as shown here, different cultivars of blueberries can have different behaviors in concentrations (Fig. 5), coupled to GSH concentrations (Fig. 6). This effect is a consequence of the coupled redox pathways of these two antioxidants in the Halliwell Foyer cycle (Foyer and Noctor, 2011).

Previous work has shown that 1-MCP treatment does not affect anthocyanins and phenolics concentrations or antioxidant activities, but does retard weight loss in 'Lateblué cultivar (Chiabrando and Giacalone, 2011). However, when 1-MCP was added after a modified atmosphere treatment it did not affect the percentage of marketable fruit in 'Burlingtoń and 'Covillé cultivars (DeLong et al., 2003). In the present work, applications of 1-MCP and GSNO improved AA and GSH 
concentrations and fruit firmness in 'Blue Cuinex́ fruit.

Increased total antioxidant capacity has been reported in blueberries by Connor et al. (2002) and Kalt et al. (1999), but their studies did not address specific antioxidants such as AA or GSH during cold storage for periods of 2 weeks as presented here. So, these improvements in nutritional quality could be exploited during cold storage transport of fruit without reducing the firmness of fruits. These attributes can be regarded by the retailers and consumers of 'Blue Cuinex́ fruit traded at long distances. Although these two cultivars show different response, 'Blue Cuinex́ shows an additive effect when the 1-MCP treatment is combined with GSNO treatment. 'Mistý maintains the attributes of firmness and decelerates the loose of AA and GSH concentrations (Figs. 5A-C and 6A-C respectively) when fruit was treated with 1-MCP with or without GSNO. Nonetheless, 'Blue Cuinex́ fruit treated with the combination of 1-MCP + GSNO doubled the concentration of AA and tripled the concentration of GSH after $14 \mathrm{~d}$ of cold storage without losing firmness, comparing with values found at harvest.

\section{Conclusions}

Taken as a whole, these results show that GSNO treatments could improve the effect of 1-MCP treatments in 'Blue Cuinex́ blueberries, maintaining the firmness of fruit and increasing the AA concentration while keeping the redox state reduced during cold-storage for $14 \mathrm{~d}$. On the other hand, 1-MCP treatment decelerated the firmness lose in 'Mistý fruit. This suggests a different sensitivity to 1-MCP in this cultivar, making the application of GSNO unnecessary in this case.

These studies could be complemented with other measurements of the activity or the expression of the enzymes involved in the AA synthesis pathways during postharvest life, completing the recent findings of Cocetta et al. (2012) in V. myrtillus L. Apart from this research in ascorbic acid and glutathione, the production of ethylene should be studied in more detail as when blueberry fruits are exposed to 1-MCP and/or different NO donors, as mentioned in MacLean and NeSmith (2011).

\section{Acknowledgements}

This work was supported by Agencia Nacional de Promoción Científica y Tecnológica (República Argentina), grant PICT 2013-0680.

We thank the personnel at the Experimental Station Julio A Hirschhorn (National University of La Plata) for taking care of the blueberry orchard and for kindly providing the fruit for this work. We are also grateful for the technical assistance of José Vera Bahima and María Celeste Molina Agostini in the respiratory rate assays and very especially for María Gabriela Cano, Olga Peluso and Laura K. Wahnan for their professional and priceless help on this work. We also like to acknowledge Dr Marcos Civello for his help in the firmness tests and color determinations. GGG, MES, ARC, MS and CGB are career researchers of CONICET (Argentina) and MLA is a fellowship student of CONICET (Argentina).

\section{Appendix A. Supplementary data}

Supplementary data associated with this article can be found, in the online version, at http://dx.doi.org/10.1016/j.postharvbio.2017.06. 012.

\section{References}

AOAC, 1980. Official Methods of Analysis, 13th ed. Association of Official Analytical Chemists, Washington, DC (p. 359).

Angeletti, P., Castagnasso, H., Miceli, E., Terminello, L., Concellón, A., Chaves, A., Vicente, A.R., 2010. Effect of preharvest calcium applications on postharvest quality, softening and cell wall degradation of two blueberry (Vaccinium corymbosum) varieties. Postharvest Biol. Technol. 58, 98-103. http://dx.doi.org/10.1016/j. postharvbio.2010.05.015.

Araujo, W.L., Tohge, T., Ishizaki, K., Leaver, C.J., Fernie, A.R., 2011. Protein degradation - an alternative respiratory substrate for stressed plants. Trends Plant Sci. 16, 489-498. http://dx.doi.org/10.1016/j.tplants.2011.05.008.

Atala, E., Vásquez, L., Speisky, H., Lissi, E., López-Alarcón, C., 2009. Ascorbic acid contribution to ORAC values in berry extracts: an evaluation by the ORAC-pyrogallol red methodology. Food Chem. 113, 331-335. http://dx.doi.org/10.1016/j.foodchem. 2008.07.063.

Ayaz, F.A., Kadioglu, A., Bertfoft, E., Acar, C., Turna, I., 2001. Effect of fruit maturation on sugar and organic composition in two blueberries (Vaccinium arctostaphylos and $V$. myrtillus) native to Turkey. New Zeal. J. Crop Hort. Sci. 29, 137-141. http://dx.doi. org/10.1080/01140671.2001.9514171.

Ban, T., Kugishima, M., Ogata, T., Shiozaki, S., Horiuchi, S., Ueda, H., 2007. Effect of ethephon (2-chloroethylphosphonic acid) on the fruit ripening characters of rabbiteye blueberry. Sci. Hort. 112, 278-281. http://dx.doi.org/10.1016/j.scienta.2006. 12.027.

Bartoli, C.G., Yu, J., Gómez, F., Fernández, L., McIntosh, L., Foyer, C.H., 2006. Interrelationships between light and respiration in the control of ascorbic acid synthesis and accumulation in Arabidopsis thaliana leaves. J. Exp. Bot. 57, 1621-1631. http:// dx.doi.org/10.1093/jxb/erl005.

Cheng, G., Yang, E., Lu, W., Jia, Y., Jinag, Y., Duan, X., 2009. Effect of nitric oxide on ethylene synthesis and softening of banana fruit slice during ripening. J. Agric. Food Chem. 57, 5799-5804. http://dx.doi.org/10.1021/jf901173n.

Chiabrando, V., Giacalone, G., 2011. Shelf-life extension of highbush blueberry using 1 methylcyclopropene stored under air and controlled atmosphere. Food Chem. 126, 1812-1816. http://dx.doi.org/10.1016/j.foodchem.2010.12.032.

Cocetta, G., Karpinen, K., Soukas, M., Hohtla, A., Häggman, H., Spinardi, A., Mignani, I., Jaakola, L., 2012. Ascorbic acid metabolism during bilberry (Vaccinium myrtillus L.) fruit development. J. Plant Physiol. 169, 1059-1065. http://dx.doi.org/10.1016/j. jplph.2012.03.010.

Connor, A.M., Luby, J.J., Hancock, J.F., Berkheimer, S., Hanson, E.J., 2002. Changes in fruit antioxidant activity among blueberry cultivars during cold-temperature storage. J. Agric. Food Chem. 50, 893-898. http://dx.doi.org/10.1021/jf011212y.

DeLong, J.M., Prange, R.K., Bishop, C., Harrison, P.A., Ryan, D.A.J., 2003. The influence of 1-MCP on shelf-life quality of highbush blueberry. HortScience 38, 417-418.

Dekazos, E.D., 1979. Effects of aminoethoxyvinylglycine (AVG) on bloom delay: fruit maturity and quality of 'Tifblué and 'Woodard rabbiteye blueberries. Proc. Fla. State Hortic. Soc. 92, 248-252.

Duan, J., Wu, R., Strik, B.C., Zhao, Y., 2011. Effect of edible coatings on the quality of fresh blueberries (Duke and Elliot) under commercial storage conditions. Postharvest Biol. Technol. 59, 71-79. http://dx.doi.org/10.1016/j.postharvbio.2010.08.006.

Ehlenfeldt, M.K., Martin Jr., R.B., 2002. A survey of fruit firmness in highbush blueberry and species-introgressed blueberry cultivars. HortScience 37, 386-389.

Ehlenfeldt, M.K., Meredith, F.I., Ballington, J.R., 1994. Unique organic acid profile of rabbiteye vs. highbush blueberries. HortScience 29, 321-323.

El-Agamy, S.Z.A., Aly, M.M., Biggs, R.H., 1982. Fruit maturity as related to ethylene in 'Delite'Blueberry. Proc. Fla. State Hortic. Soc. 95, 245-246.

Fava, J., Alzamora, S.M., Castro, M.A., 2006. Structure and nanostructure of the oute tangential epidermal cell wall in Vaccinium corymbosum L. (Blueberry) fruits by blanching, freezing-thawing and ultrasound. Food Sci. Technol. Int. 12, 241-251. http://dx.doi.org/10.1177/1082013206065702.

Flores, F.B., Sanchez-Bel, P., Valdenegro, M., Romojaro, F., Martinez-Madrid, M.C., Egea, M.I., 2008. Effects of a pretreatment with nitric oxide on peach (Prunus persica L.) storage at room temperature. Eur. Food Res. Technol. 227, 1599-1611. http://dx.doi. org/10.1007/s00217-008-0884-0.

Foyer, C.H., Noctor, G., 2011. Ascorbate and glutathione: the heart of the redox hub. Plant Physiol. 155, 2-18. http://dx.doi.org/10.1104/pp.110.167569.

Gündüz, K., Serçe, S., Hancock, J.F., 2015. Variation among highbush and rabbiteye cultivars of blueberry for fruit quality and phytochemical characteristics. J. Food Compos. Anal. 38, 69-79. http://dx.doi.org/10.1016/j.jfca.2014.09.007.

Griffith, O.W., 1980. Determination of glutathione and glutathione disulfide using glutathione reductase and 2-vinylpyridine. Anal. Biochem. 106, 207-212. http://dx.doi. org/10.1016/0003-2697(80)90139-6.

Hung, K.T., Chang, C.J., Kao, C.H., 2002. Paraquat toxicity is reduced by nitric oxide in rice leaves. J. Plant Physiol. 159, 159-166. http://dx.doi.org/10.1078/0176-161700692.

Jasid, S., Galatro, A., Villordo, J.J., Puntarulo, S., Simontacchi, M., 2009. Role of nitric oxide in soybean cotyledon senescence. Plant Sci. 176, 662-668. http://dx.doi.org/ 10.1016/j.plantsci.2009.02.007.

Kader, A.A., 2002. Postharvest biology and technology: an overview. In: Kader, A.A (Ed.), Postharvest Technology of Horticultural Crops, Publication 3311. University of California Agriculture and Natural Resources, pp. 39-47.

Kalt, W., Forney, C.F., Martin, A., Prior, R.L., 1999. Antioxidant capacity, vitamin C, phenolics, and anthocyanins after fresh storage of small fruit. J. Agric. Food Chem. 47, 4638-4644. http://dx.doi.org/10.1021/jf990266t.

Kopyra, M., Gwóźdź, E.A., 2003. Nitric oxide stimulates seed germination and counteracts the inhibitory effect of heavy metals and salinity on root growth of Lupinus luteus. Plant Physiol. Biochem. 41, 1011-1017. http://dx.doi.org/10.1016/j.plaphy.2003. 09.003.

Liu, M.-C., Song, W.-H., Zhu, S.-H., Zhou, J., 2007. Effects of nitric oxide and exogenous ethylene treatments on ethylene biosynthesis in feicheng peach. Agric. Sci. China 6 , 290-295. http://dx.doi.org/10.1016/S1671-2927(07)60047-9.

MacLean, D.D., NeSmith, D.S., 2011. Rabbiteye blueberry postharvest fruit quality and stimulation of ethylene production by 1-Methylcylopropene. HortScience 46, 1278-1281.

Manjunatha, G., Lokesh, V., Neelwarne, B., 2010. Nitric oxide in fruit ripering: trends and 
opportunities. Biotechnol. Adv. 28, 489-499. http://dx.doi.org/10.1016/j. biotechadv.2010.03.001.

Miller, W.R., McDonald, R.E., 1988. Fruit quality of rabbiteye blueberries as influenced by weekly harvests cultivars, and storage duration. HortScience 23, 182-184.

Paniagua, A.C., East, A.R., Hindmarsh, J.P., Heyes, J.A., 2013. Moisture loss is the mayor cause of firmness change during postharvest storage of blueberry. Postharvest Biol. Technol. 79, 13-19. http://dx.doi.org/10.1016/j.postharvbio.2012.12.016.

Perkins-Veazi, P., Collins, J.K., Howard, L., 2008. Blueberry fruit response to postharvest application of ultraviolet radiation. Postharvest Biol. Technol. 47, 280-285. http:// dx.doi.org/10.1016/j.postharvbio.2007.08.002.

Perkins-Veazi, P., 2016. Blueberry. In: Gross, K.C., Wang, C.Y., Saltveit, M. (Eds.), The Commercial Storage of Fruits, Vegetables, and Florist and Nursery Stocks. United States Department of Agriculture. Agricultural Research Service, pp. 240-242 (Agriculture Handbook Number 66).

Remberg, S.F., Rosenfeld, H.J., Lea, P., Haffner, K., Grønnerød, K., 2006. Characterization of quality parameters of highbush blueberry (Vaccinium corymbosum L.) cultivars. Acta Hortic. 715, 559-565. http://dx.doi.org/10.17660/ActaHortic.2006.715.86.

Rodarte Castrejón, A.D., Eichhloz, I., Rohn, S., Kroh, L.W., Huyskens-Keil, S., 2008. Phenolic profile and antioxidant activity of highbush blueberry (Vaccinium corymbosum L.) during fruit maturation and ripening. Food Chem. 109, 564-572. http:// dx.doi.org/10.1016/j.foodchem.2008.01.007.

Rodriguez, F.I., Esch, J.J., Hall, A.E., Binder, B.M., Schaller, G.E., Bleecker, A.B., 1999. A cooper cofactor for the ethylene receptor ETR1 from Arabidopsis. Science 283, 996-998. http://dx.doi.org/10.1126/science.283.5404.996.

Romero Rodriguez, M.A., Vazquez Oderiz, M.L., Lopez Hernandez, J., Sinal Lozano, J., 1992. Determination of vitamin C and organic acids in various fruits by HPLC. J. Chromatogr. Sci. 30, 433-437. http://dx.doi.org/10.1093/chromsci/30.11.433.
Simontacchi, M., Galatro, A., Ramos-Artuso, F., Santa-María, G.E., 2015. Plant survival in a changing environment: the role of nitric oxide in plant responses to abiotic stress. Front. Plant Sci. 6, 977. http://dx.doi.org/10.3389/fpls.2015.00977.

Singh, S.P., Singh, Z., Swinny, E.E., 2009. Postharvest nitric oxide fumigation delays fruit ripening and alleviates chilling injury during cold storage of Japanese plums (Prunus salicina Lindell). Postharvest Biol. Technol. 53, 101-108. http://dx.doi.org/10.1016/ j.postharvbio.2009.04.007.

Vicente, A.R., Ortugno, C., Rosli, H., Powell, A.L.T., Greve, C.L., Labavitch, J.M., 2007. Temporal sequence of cell wall disassembly events in developing fruits. 2. Analysis of blueberry (Vaccinium species). J. Agric. Food Chem. 55, 4125-4130. http://dx.doi. org $/ 10.1021 /$ jf063548j.

Wills, R.B.H., Leshem, V.V.V., 2000. Fumigation with nitric oxide to extend the postharvest life of strawberries. Postharvest Biol. Technol. 18, 75-79. http://dx.doi.org/ 10.1016/S0925-5214(99)00061-7.

Zaharah, S.S., Zora, S., 2011. Postharvest nitric oxide fumigation alleviates chilling injury, delays fruit ripening and maintains fruit quality in cold-storage 'Kensington Pride' mango. Postharvest Biol. Technol. 60, 202-210. http://dx.doi.org/10.1016/j. postharvbio.2011.01.011.

Zheng, Y., Wang, C.Y., Wang, S.Y., Zheng, W., 2003. Effect of high-oxygen atmospheres on blueberry phenolics, anthocyanins, and antioxidant capacity. J. Agric. Food Technol. 51, 7162-7169. http://dx.doi.org/10.1021/jf030440k.

Zhu, S., Zhou, J., 2007. Effect of nitric oxide on ethylene production in strawberry fruit during storage. Food Chem. 100, 1517-1522. http://dx.doi.org/10.1016/j.foodchem. 2005.12.022.

Zhu, S., Liu, M., Zhou, J., 2006. Inhibition by nitric oxide of ethylene biosynthesis and lipoxygenase activity in peach fruit during storage. Postharvest Biol. Technol. 42, 41-48. http://dx.doi.org/10.1016/j.postharvbio.2006.05.004. 